\title{
INJURY RISK FACTORS IN CHILDREN AND YOUTH IN PHYSICAL / SPORTS ACTIVITY
}

\author{
Marina DOBNIK \\ University of Primorska, Faculty of Mathematics, Natural Sciences and Information \\ Technologies, Applied Kinesiology \\ Glagoljaška 8, 6000 Koper, Slovenia \\ tel: +386 40779779 \\ e-mail: marina.dobnik@gmail.com
}

\section{ABSTRACT}

Purpose: The aim of the article is to define the injury risk factors in physical / sports activity and how they may correlate.

Methods: A systematic review of electronic databases MEDLINE, Google Scholar, ScienceDirect and Cinahl in May 2015 has provided potentially suitable articles, 10 of which were deemed original for a further detailed review. The studies include children and youth aged 0 to 19 and consider different possible injury risk factors in children in physical / sports activity.

Results: The majority of article authors (7) in selected studies share the opinion that rather than in girls, injuries are more common in boys. One of the authors claims that the factor of gender carries no substantial emphasis. The highest number of physical I sports activity-related injuries occurs in older children and adolescents. One of the selected studies finds that overweight youth develop a higher risk of sports injuries. The opinions of the authors differ when it comes to the level of physical / sports activity. Some authors conclude that children who are more active suffer fewer injuries, while other authors believe the actively involved children to be subject to a higher number of injuries. Younger children (up to the age of 12) are subject to injuries while involved in an unorganised type of activity, whether during active games outside or inside, walking or running freely. Older children and adolescents (aged above 12 years) sustain injuries more often in an organised type of activity.

Conclusion: Given the selected studies we were not able to introduce general conclusions regarding the connection between various injury risk factors, since all studies partially differ from each other, regarding age range of study participants, geographical sampling, selected injury risk factors, and different injury definitions. It can be concluded that a higher level of physical / sports activity brings a higher risk of injury.

Keywords: physical activity, occurrence, fractures, aerobic fitness, motor skills, health. 


\section{DEJAVNIKI TVEGANJA POŠKODB OTROK IN MLADOSTNIKOV PRI GIBALNI/ŠPORTNI AKTIVNOSTI}

\section{IZVLEČEK}

Namen: namen prispevka je ugotoviti, kateri so dejavniki tveganja poškodb pri gibalni/športni aktivnosti, ter ugotoviti morebitne povezave med njimi.

Metode: S sistematičnim pregledom elektronskih baz podatkov MEDLINE, Google Scholar, ScienceDirect in Cinahl smo v maju 2015 poiskali potencialno primerne članke in 10 izvirnih vključili v detajlni pregled. Študije zajemajo otroke in mladostnike, stare od 0 do 19 let, in raziskujejo možne dejavnike tveganja poškodb otrok pri gibalni/ športni aktivnosti.

Rezultati: Večina avtorjev člankov (7) izbranih študij je mnenja, da se večkrat poškodujejo fantje kot dekleta oziroma eden od avtorjev navaja, da je velikost efekta spola zanemarljiva. Največ poškodb zaradi G/ŠA nastane pri starejših otrocih in pubertetnikih. Ena od izbranih študij ugotavlja, da imajo debeli mladostniki večje tveganje za nastanek športnih poškodb. Pri nivoju G/ŠA so mnenja avtorjev deljena. Nekateri avtorji so ugotovili, da se aktivnejši otroci manj poškodujejo, drugi avtorji menijo, da se aktivnejši poškodujejo večkrat. Mlajši otroci (do 12 let) se največkrat poškodujejo $v$ neorganizirani obliki vadbe, med aktivno igro na prostem ali v notranjih prostorih, hojo ali tekom naokoli, starejši otroci in pubertetniki (nad 12 let) pa pogosteje v organiziranih oblikah vadbe.

Zaključek: Na podlagi izbranih študij ni mogoče podati splošnih zaključkov glede povezave med različnimi dejavniki tveganja poškodb, saj se vse študije deloma razlikujejo med sabo, bodisi s starostnim razponom udeležencev študij, z geografskim zajemom vzorca, z izbranimi dejavniki tveganja poškodb in v različni definiciji poškodb. Zaključimo lahko, da s količino G/ŠA obstaja tudi večje tveganje za nastanek poškodb.

Ključne besede: telesna dejavnost, pojavnost, zlomi, aerobna vzdržljivost, motorične sposobnosti, zdravje

\section{INTRODUCTION}

In the recent years, we have been witnessing a great transition and a growing number of scientific results of how physical / sports activity (hereinafter referred to as $\mathrm{P} /$ SA) and physical training effect growth and development, functional capacities, as well as the prevention of numerous early-stage chronic diseases, regarded as the results of the P / SA level in adulthood (Završnik \& Pišot, 2005).

Although P / SA brings numerous health benefits, e.g. affecting the fundamental motor skills (Okely, Booth, \& Patterson, 2001), preventing obesity (Wong et al., 2008), 
coronary heart disease, type 2 diabetes mellitus, hypertension, and osteoporosis (Hallal, Victoria, Azavedo, \& Wells, 2006), it also presents a certain injury risk. Given the physical and physiological differences between children and adults, children seem to be more susceptible to certain injuries, e.g. slipped capital femoral epiphysis and "Osgood-Schlatter's" (Emery as cited in Theisen et al., 2014). Consequently, the results from studies in adults cannot be used to describe the extent and injury risk factors in children. Injuries in children are generally less serious than in adults (Collard et al., 2008); however, they are more frequent in sports and physical activities, and are, as such, of great importance for public health and as an economic burden. The long-term consequences of sports injuries in childhood often emerge in adulthood (accelerated development of osteoarthritis) (Saxon, Finch, \& Bass, 1999). Along with the P / SA-related short- and long-term consequences, medical costs arise (economic burden to a country). The social and economic effect encompasses the indirect injury-related costs as well, e.g. the absence from work of parents of injured children (sick leave due to rehabilitation programme and health care of injured children, transportation to physiotherapy facilities, etc.) (Cumps, Verhagen, Annemans, \& Meeuse, 2008).

The key to developing preventive programmes is to define the P / SA-related injury risk factors and mechanisms (van Mechelen et al. as cited in Collard et al., 2008). Risk factors are divided into two categories (van Mechelen et al. as cited in Collard et al., 2008; Meeuwisse et al., 2007; Frisch, Croisier, Urhausen, She, \& Theisen, 2009):

- intrinsic risk factors or characteristics related to individuals, including age, gender, body composition, previous injuries, aerobic fitness, and skill level;

- extrinsic (environmental) risk factors or characteristics not related to individuals, including sports factors, protective equipment, and sports equipment.

The following paragraphs will concentrate on the selected intrinsic P / SA-related injury risk factors, since mixed opinions and findings are common in these cases. Using the term P / SA, any movement having higher energy consumption than inactivity (Pišot, 2004) will be taken into consideration. This means all types and forms of physical / sports activity, including physical activities in school, at home, in leisure time, outside, in sports, when going to school, etc.

\section{Age}

There are several studies that consider age a possible injury risk factor; these studies differ though, since they focus on a narrow age range, which makes it difficult to determine any possible connections between age and injury incidence. Moreover, different research methods are used. Apparently, the authors of the studies ascertain that children aged 13 or more face a higher injury risk than younger children (Emery as cited in Theisen et al., 2014). Similar goes for young athletes, since athletes in puberty are more susceptible to injuries than athletes who have not reached puberty yet. It has been ascertained that team sports represent a higher risk factor (up to 2 times) compared to individual sports (Frisch, Urhausen, Croisier, Windal, \& Theisen, 2011). 


\section{Gender}

The authors have a mixed opinion on gender being an injury risk factor. Several articles show that boys develop a higher risk of injuries (Fras, 2002; Koprivnik et al., 2012); however, the findings seem to depend on the specificity of the injuries. This is why Murphy et al. (2002) determine that girls are subject to a higher risk of anterior cruciate ligament injury, as well as severe knee injuries. We find the studies to be very diverse, which again makes the generalisation of the results difficult.

\section{Body composition}

We have observed that quite a few studies search for the connections between body composition and injuries, but the results cannot be generalised, since different authors resort to different techniques for measuring body composition, e.g. height and mass, lean muscle mass, body fat content or body mass index (Murphy et al., 2002). Emery (as cited in Theisen et al., 2014) ascertains that taller and heavier athletes are more susceptible to injuries; however, the relationship between the body size and the performance variable is not necessarily linear (Welsman \& Armstrong as cited in Collard et al., 2008).

\section{Physical abilities}

In literature, there are only a few studies that mention the connection between aerobic fitness and injuries. The authors of these studies use different terminology to characterise the term aerobic fitness, which makes it hard to compare various conclusions (Taimela et al., 1990). In connection with physical abilities, personal characteristics have a special meaning - not only for success in sports but also for preventing injuries; it has been ascertained that poor balance (shown as an example of risk factor in soccer) was connected to a higher risk of ankle sprains in older adolescent soccer players (McGuine \& Keene, 2006), while in younger soccer players this connection could not be observed (Frisch et al., 2011). Some findings show that the strength of individual muscle groups could be connected to a specific injury such as the rupture of the anterior cruciate ligament (Hewett et al., 2005) or ankle sprains (Willems et al., 2005); however, there is no certain way of determining the connection between the strength of muscles and sports injuries in general (Frisch et al., 2011).

The fact that different studies provide different injury definitions needs to be emphasised. Some authors only concentrated on injuries that required medical or professional attention, while others focused on injuries where professional attention was not needed and home treatment sufficed; additionally, there are others who only considered sports injuries. As such, this vast range of injury definitions between individual studies could 
affect the results of the studies and, consequently, lead to a poor comparison of the findings. This demands a careful approach to the use of injury definitions.

Due to a current low level of activity in children and youth, lately there have been efforts emerging to raise the levels of physical activity, aerobic fitness and motor skills in children and youth. Until now, little attention in literature has been paid to the question, whether it would be logical to expect a higher number of injuries when given a higher level of physical activity or whether a higher level of physical activity, better aerobic fitness or motor skills could protect children from suffering from injuries during physical activity or even in other circumstances.

Therefore, we will try to find out whether gender, age, weight, type of exercise and level of P / SA present the P / SA-related injury risk factors.

\section{METHODS}

Electronic databases MEDLINE, Google Scholar, ScienceDirect and Cinahl were used to search for suitable literature sources, including the articles published until May 2015. Different keywords were used in search combinations: "risk factors", "physical activity", "children", "youth", and "injuries". Based on the keywords given we found a database of potentially suitable articles that would be used in the analysis. After reviewing the articles and based on their suitability we have opted for the ones that would be included in a detailed review.

Different criteria for including/rejecting an individual study have been set for the article purposes:

- the participants in the study are children or youth of both genders aged 0 to 19;

- the study focuses on the connections among the intrinsic P/ SA-related injury risk factors;

- the study includes a control group;

- the study is prospective, cross-sectional, and longitudinal.

\section{RESULTS}

\section{Overview of Studies}

Among the potentially suitable articles found in electronic databases, ten (Table 1) were selected for a detailed discussion according to their suitability; six of them are based on a cross-sectional study, three on a prospective cohort study, and one on a longitudinal study, all of which had been carried out in the Netherlands, Australia, Switzerland, USA, Canada and Ireland. Individual studies encompass children and youth aged 0 to 19, with the size of the sample from 100 to 7041. Both, boys and girls were included in all studies. 
Questionnaires were used to gather the information on P / SA and other injury risk factors in children and youth, participating in the studies. One of the studies included gathering information on P / SA (extent, duration, and intensity) with the use of accelerometers (Martin-Diener, Wanner, Kriemler, \& Martin, 2013).

Information for researching the injuries that occurred during the studies were gathered with the use of questionnaire-reports on a weekly basis (Bloemers et al., 2012; Clark, Tobias, Murray, \& Boreham, 2011), with the use of two-week reports by the parents of children, included in the studies (Schwebel, Binder, McDermott Sales, \& Plumert, 2002), two-month parents' reports (Spinks, Macpherson, Bain, \& McClure, 2006), and reports after a 12-month period according to parents' recall (Martin-Diener et al., 2013; Richmond, Kang \& Emery, 2012; Emery \& Thyreman, 2009; Michaud, Renaud \& Narring, 2001) as well as reports after a 12-month period according to children's recall (Williams, Wright, Currie, \& Beattie, 1998). All the studies reported all possible injuries, except for the Clark et al. (2011) study which mentioned only fractures, and the Richmond et al. (2012) and Emery et al. (2009) studies which focused only on sports injuries. For two years the Brudvik (2000) study kept track of all the hospital-treated injuries that occurred in children involved in P / SA. Filling out the questionnaires, the circumstances of individual injuries were clarified by the parents of the injured children.

The Bloemers et al. (2012) study defined injuries as all the injuries that caused a pause in previous activities; the Spinks et al. (2006) study defined all the injuries that required administering first aid; the Martin-Diener et al. (2013), Brudvik (2000) and Michaud et al. (2001) studies defined all the injuries that required medical or professional attention; the Schwebel et al. (2003) and Williams et al. (1998) studies defined all the injuries where professional attention was not needed and where home treatment sufficed, or where a visit to a doctor or a hospital was paid; the Richmond et al. (2012) study defined all the injuries that required medical attention; the Emery et al. (2009) study defined all sports injuries that occurred in the last year, and the Clark et al. (2011) study defined all the fractures regardless the trauma level.

All the studies were searching for connections between different injury factors and $\mathrm{P} / \mathrm{SA}$. The gender and age of study participants were considered possible risk factors by all studies. Other injury risk factors were the P / SA level (Spinks et al., 2006; Martin-Diener et al., 2013; Richmond et al., 2012; Emery et al., 2009; Williams et al., 1998; Michaud et al., 2001), the type of exercise (organised/unorganised type) (Spinks et al., 2006; Martin-Diener et al., 2013; Schwebel et al., 2003; Richmond et al., 2012; Emery et al., 2009; Brudvik, 2000; Williams et al., 1998; Michaud et al., 2001), the environment where the injuries occurred (school, other) (Spinks et al., 2006; Brudvik, 2000), the type of sports (Spinks et al., 2006; Clark et al., 2011; Emery et al., 2009, Brudvik, 2000; Michaud et al., 2001), the level of aerobic fitness (Martin-Diener et al., 2013; Clark et al., 2011), selected motor skills (Martin-Diener et al., 2013; Clark et al., 2011), body mass index (Martin-Diener et al., 2013; Richmond et al., 2012; Clark et al., 2011; Emery et al., 2009), and bone mass (Clark et al., 2011). 


\section{Age as Injury Risk Factor}

The fact that the selected studies deal with different age groups makes it hard to present accurate and reliable findings. Arranging studies into groups according to the approximate combined age of the participants, we see there are mixed opinions on the matter. The Martin-Diener et al. (2013) study shows that children between the ages of 8 and 9 are subject to a higher risk of injury when compared to children aged 7 to 8 (the study included children between the ages of 7 and 9). The Schwebel et al. (2003), Emery et al. (2009), Brudvik (2000) and Williams (1998) studies show that according to the age of the participants (6-8 years; $12-15$ years; $0-6$ / 6-15 years and $11,13,15$ years of age) there are no statistically significant distinctions in injuries. Although the Brudvik (2000) study finds no statistically significant distinctions in injuries according to the age of participants, it shows that girls are more prone to injuries around the age of 2 and between the ages of 10-12, while boys are subject to injuries almost equally as often, regardless of age. The Williams et al. (1998) study also finds that older children (15) develop a slightly higher risk of injuries than younger children (aged 11 and 13). The same study claims that the number of P / SA-related consequences (injury occurrence) increases in relation to age and is most common in 15-year-olds. The Bloemers et al. (2014) study determines that the majority of all injuries occurs between the ages of 10 and 11 (the study included children aged 10 to 12). The Richmond et al. (2012) study ascertains that older adolescents (18-19 years old) are subject to a higher risk of medically-treated injuries when compared to younger adolescents (12-17 years old); however, children aged 14 to 15 face the highest risk of injury in all types of injuries, not only the medically-treated. This statement is consistent with the results of the Clark et al. (2011) study, since it shows that children aged $14.1 \pm 1.5$ suffer more fractures than children aged $13.8 \pm 1.5$ (the study included children and youth between the ages of 12 and 16). The latter is also consistent with the findings of the Michaud et al. (2001) study which claims that the frequency of all injuries increases between the ages of 9 and 16 (peaking between the ages of 14 and 16) and decreases afterwards. A similar frequency applies to all the P / SA-related injuries.

\section{Gender as Injury Risk Factor}

Considering all the injuries (occurring in leisure time and during organised activity), the Spinks et al. (2006) and Michaud et al. (2001) studies ascertain that boys suffered more injuries than girls (the Spinks et al. (2006) study claims this number to be even twice as high). The Schwebel et al. (2003), Clark et al. (2011), Brudvik (2000) and Williams (1998) studies also find the injury risk level slightly higher in boys. On the contrary, the Bloemers et al. (2014) study, performed on children aged 10 to 12 , finds the injury risk factor higher in girls than in boys. The Martin-Diener et al. (2013), Richmond et al. (2012), and Emery and Tyreman (2009) studies observe no connection between gender and risk of injuries. However, the Emery et al. (2009), Brudvik (2000), 
and Michaud et al. (2001) studies find that gender as injury risk factor in sports injuries is closely related to other injury risk factors, e.g. type of sports and type of injury. The Emery et al. (2000) study shows that according to the type, most common injuries in boys are concussion, fracture or bleeding, while in girls these injuries are ligament sprains and muscle strains. The Williams et al. (1998) study reports of most common type of injuries in girls to be ligament sprains and dislocations, while in boys most common injuries are dislocations (especially of the lower extremities) and fractures.

\section{P / SA Level as Injury Risk Factor}

Lately, the P / SA level has become the main topic. The term describes the weekly amount, duration and intensity of $\mathrm{P} / \mathrm{SA}$. One of our goals was to determine whether there is a connection between the P / SA level (low, mid, and high) and a higher risk of injuries. The Bloemers et al. (2012) study observes a direct connection between the P/ SA level and the P / SA-related injuries, namely the risk of injuries having decreased by the increase in the P / SA level and the most active children being subject to the lowest risk of injuries, respectively (the study was performed on children aged 10 to 12). On the contrary, the Richmond et al. (2012) study, performed on children and youth aged 12 to 19 , reports of the connection between the level of physical activity and all types of sports injuries, proving that the participants on a higher level of physical activity are subject to a 4.2-times higher risk of injuries when compared to the participants on a lower level of physical activity. A similar opinion is expressed in the Emery et al. (2009) study, determining an increased risk of sports injuries when the extent and the duration levels of P / SA are higher. Regarding the level of physical activity, the Martin-Diener et al. (2013) study, performed on children aged 7 to 9, shows a higher injury incidence in girls than in boys. On the contrary, the Spinks et al. (2006), Williams et al. (1998), and Michaud et al. (2001) studies ascertain the boys to be more active than the girls and at the same time to be subject to up to twice as many injuries. The Spinks et al. (2006) study finds that according to the number of hours of physical activity most injuries in children occur during an organised type of exercise (participants aged 4 to 12). The Richmond et al. (2012) study observes the same fact with sports injuries (participants aged 12 to 19$)$.

\section{Type of Exercise as Injury Risk Factor}

In the following part we focused on different types of exercise. The Martin-Diener et al. (2013) study has ascertained that the majority of P / SA-related injuries occur while playing outside or inside and during free (unorganised) walks or runs, regarding children between the ages of 7 and 9. The Schwebel et al. (2003) study reports of the same fact in children aged 6 to 8 . This result is consistent with the result of the Spinks et al. (2006) study that observes 504 P / SA-related injuries during the experiment, 314 (62 
$\%)$ of which occurred outside of school environment, with 94 (30\%) cases presenting serious injuries that demanded professional attention. While the Bloemers et al. (2014) study finds no connection between physical education in school and increased risk of injuries in children aged 10 to 12, the Richmond et al. (2012) and Michaud et al. (2001) studies discover a slightly increased risk of injuries in organised types of exercise. Similar conclusions are drawn also by the Emery et al. (2009) study, determining that among all the children suffering at least one injury at the time of the study, there were $70.53 \%$ of those who had been taking part in organised sports activities, either in clubs or in school sports teams, where the injuries occurred. Similar conclusions are also mentioned in the Williams et al. (2009) study which finds that $25.1 \%$ of all the injuries occur within the official sports activities (organised in schools or clubs), whereas $7.9 \%$ occur during unorganised types of exercise.

\section{Physical and Functional Capacities as Injury Risk Factor}

We were interested in exploring physical capacities and aerobic fitness in children and youth, since it is a very interesting and rarely investigated P / SA-related injury risk factor, and especially because the opinions on the matter in the available literature and in public are very diverse. Among the studies reviewed, the Martin-Diener et al. (2013) study, performed on children aged 7 to 9, proved that a low level of aerobic fitness and a high level of motor skills are connected to the risk of injuries, given the level of impartially measured P / SA. The study also showed that injury incidence was higher in children with the lowest level of aerobic fitness, compared to those with the mid-level of aerobic fitness. Injury incidence was higher in children with a high level of motor skills, compared to those with a normal range of motor skills. While the Clark et al. (2011) study observed the fact that there is a positive connection between aerobic fitness and fractures - the highest incidence of fracture was noticed in participants with low-strength fist clenching - it could not establish the connection between high-strength fist clenching and a high level of aerobic fitness. The study also showed that children with a higher level of aerobic fitness, suffering from fractures, were taller, meaning this study proved that individuals with the highest level of aerobic fitness and the lowest strength in fist clenching were subject to a higher risk of fracture. Additionally, the study showed that the individuals with the highest level of aerobic fitness and the lowest vertical jump were subject to a higher risk of fracture as well. Bone mass can be regarded as one of the most interesting risk factors. The Clark et al. (2011) study ascertained a strong connection between the strength of fist clenching and the bone mass measurements. The authors believe that muscles can play a very important role in protecting the bones, since they absorb the extra shock or stress. 


\section{Body Mass Index as Injury Risk Factor}

One of the most interesting P / SA-related injury risk factors is the body mass index of children or youth. The Martin-Diener et al. (2013), Clark et al. (2011), Bloemers et al. (2012), and Emery et al. (2009) studies did not find any connection between overweight children (aged 7 to 9, 12 to 16, 10 to 12, and 12 to 15) and an increased risk of injuries. The Richmond et al. (2012) study also could not show any statistical connection between all the injuries and the overweight youth, when compared to the normal-weight youth aged 12 to 19 . The same study found a connection between overweight youth and an increased risk of all injuries, namely overweight youth develops a higher risk of sports injuries, when compared to normal-weight youth (this connection could not be seen in professionally attended injuries). The majority of studies in our review did not report of height as a possible $\mathrm{P}$ / SA-related injury risk factor, except for the Clark et al. (2011) study, which could not establish this connection.

\section{DISCUSSION}

Studies included in the overview share the opinion that P / SA is beneficial to children's health, although it can increase the risk of possible injuries. It is difficult to find existing studies in the literature which deal with the same injury risk factors in children of the same age. Common injury risk factors in the studies included in the overview are age and gender. Besides age and gender, the chosen studies performed in different countries, pertaining to different age groups, research other injury risk factors as well (different among studies). Thus, it is difficult to define the common guidelines and offer opinion on the results of the mentioned studies.

Different studies offer no clear definition on physical activity-related injuries. A $\mathrm{P}$ / SA-related injury is a common term used to describe injuries which occur during different physical and/or sports activities and differ in their severity (serious and less serious injuries). Definitions of injuries in selected studies include either all injuries (Bloemers et al., 2012; Schwebel et. al, 2003), or all injuries where administering first aid (Spinks et al., 2006) or medical personnel (Martin-Diener et al., 2013; Brudvik, 2000; Michaud et al., 2001) were required, sports injuries alone (Richmond et al., 2012; Emery et al., 2009), or fractures alone (Clark et al., 2011). If P / SA-related injuries were noted only through medical channels (Martin-Diener et al., 2013; Brudvik, 2000), mostly severe or serious injuries were registered, without any records of less serious injuries. It is evident that it is hard to offer general findings on P / SA-related injuries, based on the published data of selected studies. We are well aware that studies depend on local conditions and are often directed towards researching the problems of individual sports disciplines.

Opinions on the connection between the P / SA-related injuries and the age factor are not standardised. The results of the selected studies foresee that older children and adolescents are most exposed to such injuries. These two groups are more frequently 
involved in organised sports and opt for more dangerous leisure activities; they are on the brink of or have already reached puberty in which a non-linear process of growth is present. Apart from that, children of the same chronological age can differ greatly in the sense of their biological maturity and development. Since the studies presented here (except for the Michaud et al. (2001) study) do not report on the chronological and biological age of the participants simultaneously, it would be logical to study both combinations in the future. The Michaud et al. (2001) study emphasises a higher risk of injuries regarding a child's biological growth in comparison to the actual body weight, height, body mass index, and chronological age.

Gender is the next injury risk factor on which the opinions differ substantially. The majority of the authors of selected studies believes that boys are more prone to injuries (Spinks et. al, 2003; Clark et al., 2011; Michaud et al., 2001; Schwebel et al., 2003; Clark et al., 2011; Brudvik, 2000; Williams et al., 1998) than girls, or that these connections are negligible (Martin-Diener et al., 2013; Schwebel et al., 2003). The prevailing opinion of the general public is that boys get injured more often than girls; the reason behind it can perhaps be found in the fact that boys are usually more courageous (aggressive) than girls, they take part in more lively sports activities (soccer, basketball, etc.) in comparison to girls (e.g. dancing, etc.), and are therefore exposed to more opportunities to injure themselves (Taimela et al., 1990). The reasons for injuries in girls could include anatomic, hormonal and neuromuscular factors (Murphy et al., 2002). Adolescent girls usually reach their maximum height approximately at the age of 12 , which makes them clumsier and more prone to injuries during this period. It is possible that the results differ in regards to the fact which geographical area the study was performed in. It would be interesting to study the correlation between the gender and the age of children and youth and the P / SA-related injuries in Slovenia.

Since there have been a lot of efforts over the past few years to increase P / SA among children and youth, the findings concerning the P / SA intensity level and the P / SA-related injuries are of great interest. Some authors believe that more active children are less prone to injuries (Bloemers et al., 2012; Martin-Diener et al., 2013), while others feel that more active children are more likely to get injured (Richmond et al., 2012; Williams et al., 1998; Emery et al., 2009). A question that arises here is which child is active and which one inactive, and where the line between both groups of children can be drawn. Almost all studies have measured the level of physical activity with questionnaires (the question of the reliability of answers arises), while the Martin-Diener et al. (2013) study was the only one that used accelerometers, producing impartial results.

An interesting P / SA-related injury risk factor is also the body mass index in children and adolescents. Most authors of these studies who have researched this correlation (Martin-Diener et al., 2013; Clark et al., 2011; Richmond et al., 2012; Emery et al., 2009) did not find any connection between over-weight children (aged 7-9, 12-16, 12-19, 12-15) and the increased P / SA-related injury risk. Moreover, Richmond et al. (2012) determined that over-weight young people are more sports injury-prone than those of normal weight. It should be taken into account that the latter authors focused mainly on sports injuries and not on any other potential injuries that could arise during 
$\mathrm{P}$ / SA. It should also be clear that all the studies which research the mentioned correlation (Clark et al., 2011; Martin-Diener et al., 2013; Richmond et al., 2012; Emery et al., 2009) used the data on height and weight of each individual for the measuring of the body mass index. More precise and reliable results could be attained by body composition analysis measurements. Strel et al. (2008) determined that in the period between 1987 and 2007 the share of over-weight and obese young people in Slovenia, aged between 6 and 19, increased from $15.6 \%$ to $28.9 \%$ in boys and from $15.6 \%$ to $24.1 \%$ in girls. Other authors (Malina et al., 2005; Pišot \& Planinšec, 2005) also determined that the modern way of living influences the increase in over-weight body mass, which can often lead to improper physical and motor-skill development (Horvat \& Magajna, 1989; Marjanovič \& Zupančič, 2004). The mentioned process can be transferred also onto the active period of adulthood (Fras, 2002) and results in different injuries and illnesses, which effectively decreases the quality of life of an individual and the society as a whole. It would be interesting to study whether over-weight children are also clumsier and inept or if they have disproportionally developed elementary motor-skill patterns, and are consequently not taking part in physical activities enough or spend their leisure time mainly in front of computers and TVs.

As mentioned in the results chapter, the field of motor-skill development, as a potential predictor of injuries, often remains overlooked. There are opposing opinions on this subject in the selected studies. Early studies (Angle as cited in Schwebel et al., 2002) mention PE teachers who assessed that children with inferior motor skills suffer more injuries in school environment. Others have established that boys with better motor skills (assessed by their mothers) and girls (assessed by sports educators) get injured more often (Angle as cited in Schwebel et al., 2002). An extensive study, made in the 1980s about children's motor skills and injuries, was a longitudinal study which included 822 children from Dunedin in New Zealand. In the study, children were observed from their birth up to the age of 7 (Langley, Silva, \& Williams as cited in Schwebel et al., 2002). It was determined that stronger and motorically more skilled children injured themselves more often, while a positive correlation between the child's history of injuries (from their birth up to age 7), bigger muscular strength and dexterity was also determined. It was also established that agility and delicate motor skills are not connected to the history of injuries. The findings of studies from the past are quite different and mixed. Positive as well as negative relations between both variables were observed in the past. One of the most comprehensive studies up till now (Langley et al. as cited in Schwebel et al., 2002) determined a positive correlation between an injury and well-developed motor skills - especially strength, followed by coordination, balance, and agility. This finding is contrary to the belief that clumsy children (those with bad coordination and balance) get injured most often.

If motorically (less) capable or (in)competent children are to be related to the findings of the selected studies, in which authors dealt with organised and non-organised exercise, some interesting questions can be posed and connections established. Martin-Diener et al. (2013) have determined in their study that most physical activity-related injuries in children aged 7 to 9 occur while playing outside or inside, while walking 
or running freely - unorganised activities. These findings have also been confirmed by Schwebel et al. (2003) in their study which included children of ages between 6 and 8, and Spinks et al. (2006) who determined that the majority (62\%) of all injuries occurred outside the school environment. The Brudvik (2000) study also determines that $62 \%$ of children aged $0-6$ are subject to injuries occurring at home or in the close proximity, while only $13 \%$ of children's injuries occur in the kindergarten; $37 \%$ of children aged 6-15 sustain injuries at home, $25 \%$ in school, and $10 \%$ in organised sports activities. What is also interesting are sports injuries mentioned in the Emery et al. (2009) study, including 12-15-year-olds, where the study finds that the majority of sports injuries $(70.53 \%)$ occur in organised types of activity, either in clubs or school sports teams. Thus, we can deduce that younger age groups (mainly pre-school children or lower-grade school children) sustain injuries more often during leisure or unorganised activities, whereas older children (aged 12 and above) tend to take part in organised types of exercise more often, which results in more injuries.

In the future, it would be sensible to study in greater detail why most injuries in children of lower age groups occur during their leisure time (during unorganised activities), when they are left to do what they want. Are these injuries a result of the (in)consistency of elementary motoric patterns, physical characteristics, child's motor skills, or maybe the over-protectiveness of their parents or the environment itself or maybe even of overestimating their own physical abilities. Therefore, future studies, made on the basis of the mentioned results and findings, should form a model which would predict the possibility of injuries on the basis of predicators, deriving from the consistency of elementary motoric patterns, physical characteristics, and motor skills.

\section{CONCLUSION}

The development in the early childhood is very dynamic and wholesome. Within this period, P / SA are of great significance, since they represent important means for acquiring different information and new experience as well as for the development of motor and functional capacities. Children are most susceptible to the changes and the development of skills and knowledge as well as to the adaption to the environment and its characteristics before they hit puberty (Pišot \& Planinšec, 2005). I believe that children or adolescents will acquire experience only by being free and allowed to make their own mistakes, go through some awkward situations such as for example the P / SA-related injuries, thereby testing the limitations of themselves and the world around them. To make their journey as painless as possible, it is up to us to include children in an encouraging environment right from the start, in which they will be able to develop their motor skills and gather motor-skill knowledge and experiences. In order to secure such an encouraging environment, it is important to research the field of P/ SA-related injuries and injury risk factors in greater detail.

In regards to the chosen studies and their findings, reliable conclusions actually cannot be drawn, since different studies are based on different data and a different selection 
Marina DOBNIK: INJURY RISK FACTORS IN CHILDREN AND YOUTH IN PHYSICAL / SPORTS ACTIVITY, 39-57

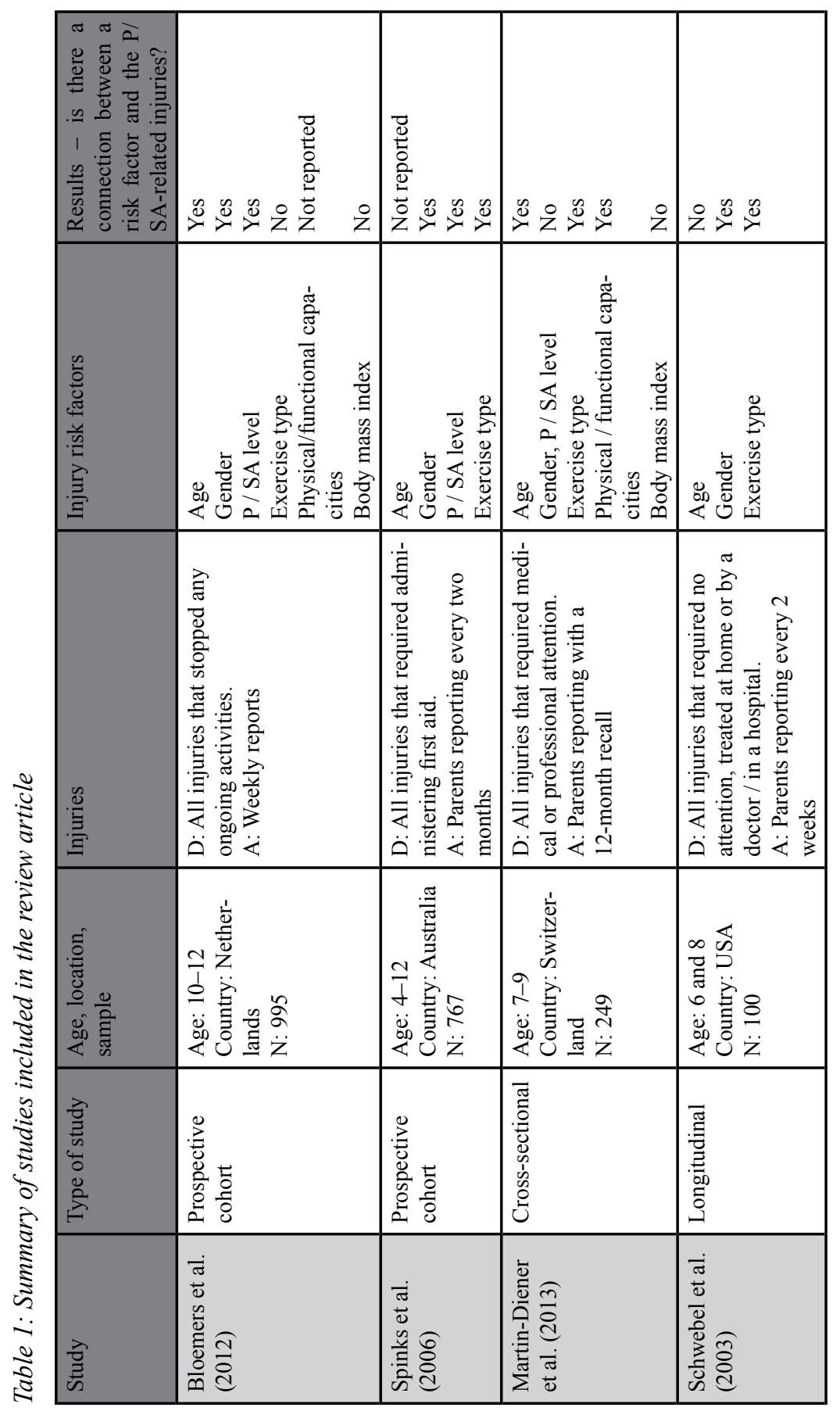




\begin{tabular}{|c|c|c|c|c|c|}
\hline 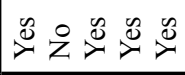 & $\stackrel{\infty}{\infty})^{\infty}$ & 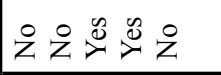 & $\stackrel{\infty}{\infty} \triangleq$ & 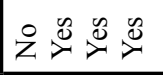 & 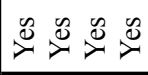 \\
\hline 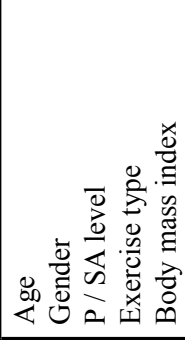 & 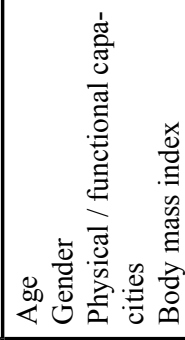 & 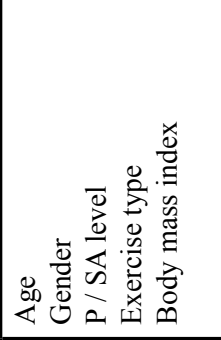 & 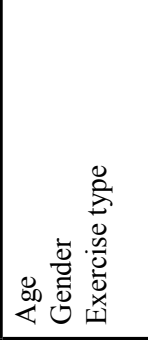 & 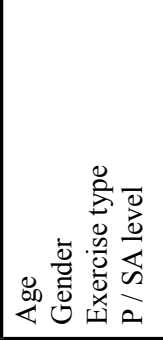 & 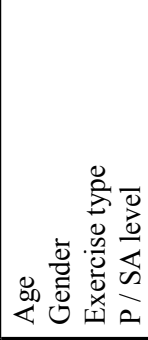 \\
\hline 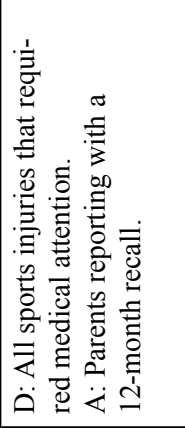 & 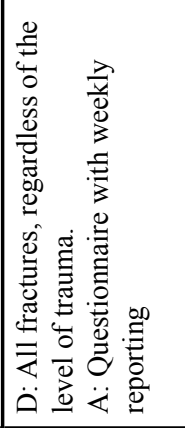 & 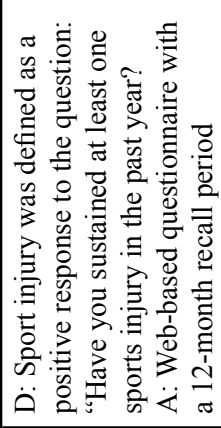 & 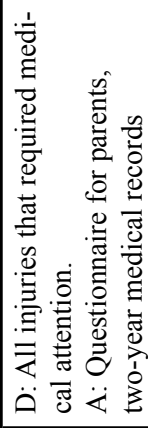 & 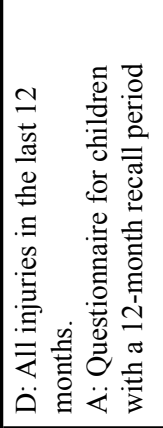 & 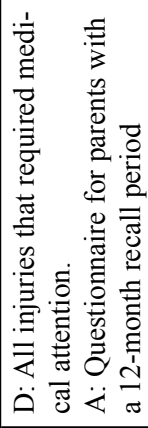 \\
\hline 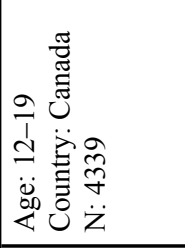 & 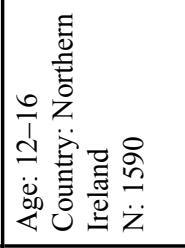 & 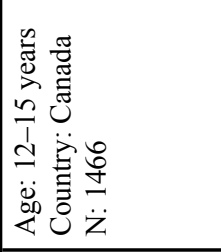 & 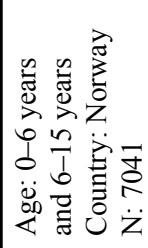 & 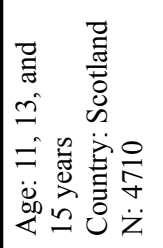 & 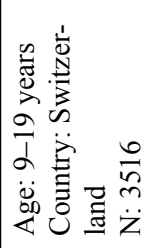 \\
\hline 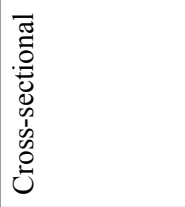 & 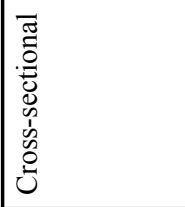 & 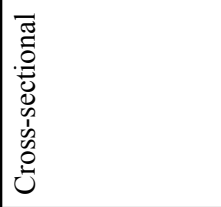 & 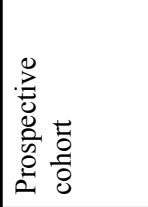 & 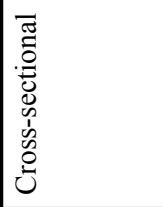 & 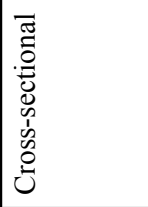 \\
\hline 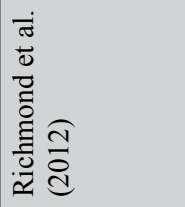 & 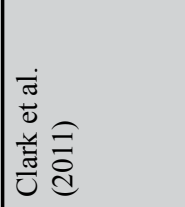 & 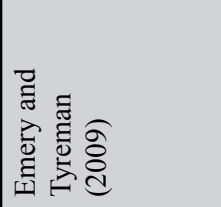 & 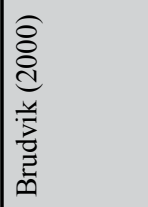 & 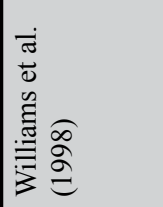 & 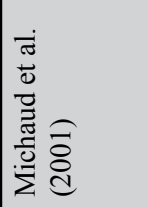 \\
\hline
\end{tabular}

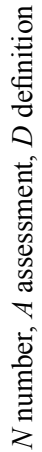


of risk factors, which limits our conclusions. It is confusing that the same risk factors in different studies bring different results. On the one hand, some studies offer positive correlations, while on the other there are negative correlations - there is no common denominator. Maybe this depends on the geographic area in which the study was made. Although primarily selected studies, which in individual parts explained different levels of P / SA-related injury-occurrence, differed methodologically, they showed P / SA-related injuries to be significant, representing a large portion of all injuries among children and adolescents in different countries of the world. The fact that injuries usually do not occur due to just one risk factor, should also be taken into consideration. The results would probably be more standardised if the selected studies included injury risk factors in a more complex manner.

If we take for example the level of P / SA as an injury risk factor, some authors of the selected studies predominantly determined that more active children get injured less often, but on the other hand, other authors determined just the opposite. Therefore, it would be sensible to determine the correlations between completely non-active children and active children who take part in P / SA and are therefore more exposed to injuries, and, thereby, to establish what influences the occurrence of such injuries. Perhaps the reason lies in the (in)consistency of elementary motoric patterns, in physical characteristics, perhaps in a child's motor skills, parents' over-protectiveness, in the environment or in overestimating one's own physical capabilities.

To develop an appropriate policy and prevention strategies in Slovenia, concerning the prevention of P / SA-related injuries among children and adolescents, it would be wise to thoroughly study different P / SA-related injury risk factors in children. Thus, the definition of P / SA-related injuries should be unified, taking into account formal (organised) types of sports exercise as well as informal (unorganised, leisure) types of physical activities. The injuries differ in type (sprain, fracture, dislocation, etc.) and mechanism. It should be taken into account that sports disciplines differ significantly, meaning that all injuries sustained in sports activities should not be generalised for all sports disciplines. Each sports discipline has its own set of rules and characteristics, within which there are specific risk factors which demand special attention (especially of the coaches in organised sports disciplines). Within each sports discipline we can expect certain types and mechanisms of injuries to have a greater occurrence probability. As already mentioned, the results of the selected studies cannot be generalised, since studies pertain to different age groups. Can the sample in the selected studies actually represent the entire population? All these are methodological limitations, due to which all the data on P / SA-related injuries in the selected studies and other published literature differ.

Therefore, the selected studies are a good starting point towards the direction, mentioned already in the discussion - towards establishing a model which would predict the possibility of injury occurring on the basis of predicators, deriving from the consistency of elementary motoric patterns, physical characteristics, and motor skills. With such a model of predicting and classifying injuries, the findings could maybe predict the trends being introduced in these fields, and by that provide the possibilities for the de- 
velopment and establishment of intervention measures and introduce some guidelines for the prevention of injuries due to child's potential motoric (in)competence. Pišot et al. (2010) allow the presumption that besides external factors the effects of unsatisfactory acquiring of elementary motoric patterns and incorrect physical development or insufficient motoric competences are the key factors in fall-related injuries.

\section{Acknowledgement}

$\mathrm{PhD}$ Study of Marina Dobnik is being partly financed by the European Union (European Social Found).

\section{REFERENCES}

Angle, C. R. (1975) as cited in Schwebel, D. C., Binder, S. C., McDermott Sales, J., \& Plumert, J. M. (2002). Is there a link between children's motor abilities and unintentional injuries? Journal of Safety Research, 34(2), 135-141. VIEW ITEM

Bloemers, F., Collard, D., A Paw, Mai Chin., Van Mechelen, W., Twisk, J., \& Verhagen, E. (2012). Physical inactivity is a risk factor for physical activity-related injuries in children. British Journal of Sports Medicine, 46(9), 669-647. VIEW ITEM

Brudvik, C. (2000). Child injuries in Bergen, Norway. Injury, International Journal of the Care of the Injured, 31(10), 761-767. VIEW ITEM

Clark, E. M., Tobias, J. H., Murray, L., \& Boreham, C. (2011). Children with low muscle strength are at an increased risk of fracture with exposure to exercise. Journal of Musculoskeletal \& Neuronal Interactions, 11(2), 196-202. VIEW ITEM

Collard, D. C. M., Verhagen, E. A. L. M, Chin A Paw, M. J. M., \& van Mechelen, W. (2008). Acute physical activity and sports injuries in children. Applied Physiology, Nutrition, and Metabolism, 33(2), 393-401. VIEW ITEM

Cumps, E., Verhagen, E., Annemans, L., \& MeeuseN, R. (2008). Injury rate and socioeconomic costs resulting from sport injuries in Flanders: data derived from sport insurance statistics 2003. British Journal of Sports Medicine, 42(9), 767-772. VIEW ITEM

Emery, C. A. (2003) as cited in Theisen, D., Malisoux, L., Seil, R., \& Urhaussen, A. (2014). Injuries in Youth Sports: Epidemiology, Risk Factors and Prevention. Deutsche Zeitschrift für Sportmedizin, 65(9), 248-252. VIEW ITEM

Emery, C. A., \& Tyreman, H. (2009). Sport participation, sport injury, risk factors and sport safety practies in Calgary and area junior high schools. Paediatrics \& Child Health, 14(7), 439-444. VIEW ITEM

Fras, Z. (2002). Predpisovanje telesne aktivnosti za preprečevanje bolezni srca in ožilja. Zdravstveno varstvo, 41(1-2), 27-34.

Frisch, A., Croisier, J. L., Urhausen, A., Seil, R., \& Theisen, D. (2009). Injuries risk factors and prevention initiatives in youth sport. British Medical Bulletin, 92(1), 95-121. VIEW ITEM

Frisch, A., Urhausen, A., Seil, R., Croisier, J. L., Windal, T., \& Theisen, D. (2011). Association between preseason functional tests and injuries in youth football: a prospective 
follow-up. Scandinavian Journal of Medicine \& Science in Sports, 21(6), e468-e476. VIEW ITEM

Hallal, P. C., Victora, C. G., Azevedo, M. R., \& Wells, J. C. (2006). Adolescent physical activity and health: a systematic review. Sports Medicine, 36(12), 1019-1030. VIEW ITEM

Hewett, T. E., Myer, G. D., Ford, K. R., et al. (2005). Biomechanical measures of neuromuscular control and valgus loading of the knee predict anterior cruciate ligament injury risk in female athletes: a prospective study. American Journal of Sports Medicine, 33(4), 492-501. VIEW ITEM

Horvat, L., \& Magajna, L. (1989). Razvojna psihologija. Ljubljana: Državna založba Slovenije.

Koprivnik, H., Drev, A., Jeriček Klanšček J., \& Bajt, M. (2012). Z zdravjem povezana vedenja mladostnikov v Sloveniji - izzivi in odgovori. Ljubljana: Inštitut za varovanje zdravja Republike Slovenije.

Langley, J. D., Silva, P. A., \& Williams, S. (1980) as cited in Schwebel, D. C., Binder, S. C., McDermott Sales, J., \& Plumert, J. M. (2002). Is there a link between children's motor abilities and unintentional injuries? Journal of Safety Research, 34(2), 135-141. VIEW ITEM

Malina, R., et al. (2005). Evidence Based Phsical Activity for School-age Youth. The Journal of Pediatrics, 146(6), 732-737. VIEW ITEM

Marjanovič, U. L., \& Zupančič, M. (2004). Teorije psihičnega razvoja. In Ljubica Marjanovič Umek et al., Razvojna psihologija (pp 28-63). Ljubljana: Znanstveno-raziskovalni inštitut Filozofske fakultete.

Martin-Diener, E., Wanner, M., Kriemler, S., \& W. Martin, B. (2013). Association of objectively assessed levels of physical activity, aerobic fitness and motor coordination with injury risk in school children aged 7-9 years: a cross-sectional study. BMJ Open, 3(8). VIEW ITEM

McGuine, T. A., \& Keene, J. S. (2006). The effect of a balance training program on the risk of ankle sprains in high scool athletes. American Journal of Sports Medicine, 34(7), 1103-1111. VIEW ITEM

Meeuwisse, W. H., Threman, H., Hagel, B., \& Emery, C. A. (2007). A dynamic model of etiology in sport injury: the recoursive nature of risk and causation. Clinical Journal of Sport Medicine, 17(3), 215-219. VIEW ITEM

Michaud, P.-A., Renaud, A., \& Narring, F. (2001). Sport activities related to injuries? A survey among 0 - 19 year olds in Schwitzerland. Injury Prevention, 7(1), 41-45. VIEW $\underline{\text { ITEM }}$

Murphy, D. F., Connolly, D. A., \& Beynnon, B. D. (2003). Risk factors for lower extremity injury: a review of the literature. British Journal of Sports Medicine, 37, 13-29. VIEW ITEM

Okely, A. D., Booth, M. L., \& Patterson, J. W. (2001). Relationship of physical activity to fundamental movement skills among adolescents. Medicine \& science in sports \& exercise, 33(11) 1899-1904. VIEW ITEM

Pišot, R. (2004). Vloga in pomen gibalne/športne dejavnosti v šolskem okolju. Zdrava šola, $1,24-27$.

Pišot, R., \& Planinšec, J. (2005). Struktura motorike v zgodnjem otroštvu: motorične sposobnosti v zgodnjem otroštvu v interakciji z ostalimi dimenzijami psihosomatičnega 
statusa otroka. Koper: Univerza na Primorskem, Znanstveno-raziskovalno središče, Inštitut za kineziološke raziskave, Založba Annales.

Pišot, R., et al. (2010). Gibalno kompetenten otrok - zdrav in uspešen otrok. In J. Dolinšek, et al. (Eds.) Otrok in šport; Obravnava otrok z drisko; Šokovna stanja v otroškem obdobju: zbornik XX. srečanje pediatrov in VII. srečanje medicinskih sester v pediatriji (pp 15-26). Maribor: Univerzitetni klinični center, Klinika za pediatrijo.

Richmond, S. A., Kang, J., \& Emery, C. A. (2012). Is body mass index a risk factor for sport injury in adolescents? Journal of Science and Medicine in Sport, 16(5), 401-405. VIEW ITEM

Saxon, L., Finch, C., \& Bass, S. (1999). Sport participation, sport injuries and osteoarthritis: implications for prevention. Sports Medicine, 28(2), 123-135. VIEW ITEM

Schwebel, D. C., Binder, S. C., McDermott Sales, J., \& Plumert, J. M. (2002). Is there a link between children's motor abilities and unintentional injuries? Journal of Safety Research, 34(2), 135-141. VIEW ITEM

Spinks, A. B., Macpherson, A. K., Bain, C., \& McClure, R. J. (2006). Injury risk from popular childhood physical activites: results from an Australian primary school cohort. Injury Prevention, 12(6), 390-394. VIEW ITEM

Strel, J., Kovač, M., \& Starc, G. (2008). BMI and obesity trends of Slovenian children and youth 1987 - 1997 - 2007. Ljubljana: UL, Fakulteta za šport.

Taimela, S., Kujala, U. M., \& Osterman, K. (1990). Instrinsic risk factors and athletic injuries. Sports Medicine, 9(4), 205-215. VIEW ITEM

van Mechelen, W., Hlobil, H., \& Kemper, H. C. (1992) as cited in Collard, D. C. M., Verhagen, E. A. L. M, Chin A Paw, M. J. M., \& van Mechelen, W. (2008). Acute physical activity and sports injuries in children. Applied Physiology, Nutrition, and Metabolism, 33(2), 393-401. VIEW ITEM

Welsman, J. R., \& Armstrong, N. (2000) as cited in Collard, D. C. M., Verhagen, E. A. L. M, Chin A Paw, M. J. M., \& van Mechelen, W. (2008). Acute physical activity and sports injuries in children. Applied Physiology, Nutrition, and Metabolism, 33(2), 393401. VIEW ITEM

Willems, T. M., Witvrouw, E., Delbaere, K., Mahieu, N., De Bourdeaudhuij, I., \& De Clercq, D. (2005). Instrinsic risk factors for inversion ankle sprains in male subjects: a prospective study. American Journal of Sports Medicine, 33(3), 415-423. VIEW ITEM

Williams, J. M., Wright, P., Currie, C. E., \& Beattie, T. F. (1998). Sport related injuries in Scottish adolescents aged 11-15. British Journal of Sports Medicine, 32(4), 291-296. VIEW ITEM

Wong, P., Chia, M. Y., Tsou, I. Y., et al. (2008). Effects of 12-week exercise training programme on aerobic fitness, body composition, blood lipids and C-reactive protein in adolescents with obesity. Annals Academy of Medicine Singapore, 37(4) 286-293. VIEW ITEM

Završnik, J., \& Pišot, R. (2005). Gibalna/športna aktivnost za zdravje otrok in mladostnikov. Koper: Založba Annales, Univerza na Primorskem, Znanstveno raziskovalno središče, Inštitut za kineziološke raziskave. 